University of Nebraska - Lincoln

DigitalCommons@University of Nebraska - Lincoln

2003

\title{
Herbicides in Ground Water beneath Nebraska's Management Systems Evaluation Area
}

\author{
Roy F. Spalding \\ University of Nebraska - Lincoln, rspalding1@unl.edu \\ Mary E. Exner \\ University of Nebraska at Lincoln \\ Daniel D. Snow \\ University of Nebraska at Lincoln, dsnow1@unl.edu \\ David A. Cassada \\ University of Nebraska at Lincoln, dcassada1@unl.edu \\ Mark E. Burbach \\ University of Nebraska at Lincoln, mburbach1@unl.edu \\ See next page for additional authors
}

Follow this and additional works at: https://digitalcommons.unl.edu/watercenterpubs

Part of the Water Resource Management Commons

Spalding, Roy F.; Exner, Mary E.; Snow, Daniel D.; Cassada, David A.; Burbach, Mark E.; and Monson, Stephen J., "Herbicides in Ground Water beneath Nebraska's Management Systems Evaluation Area" (2003). Faculty Publications from The Water Center. 11.

https://digitalcommons.unl.edu/watercenterpubs/11

This Article is brought to you for free and open access by the Water Center, The at DigitalCommons@University of Nebraska - Lincoln. It has been accepted for inclusion in Faculty Publications from The Water Center by an authorized administrator of DigitalCommons@University of Nebraska - Lincoln. 


\section{Authors}

Roy F. Spalding, Mary E. Exner, Daniel D. Snow, David A. Cassada, Mark E. Burbach, and Stephen J. Monson 


\title{
Herbicides in Ground Water beneath Nebraska's Management Systems Evaluation Area
}

\author{
Roy F. Spalding,* Mary E. Exner, Daniel D. Snow, David A. Cassada, Mark E. Burbach, and Stephen J. Monson
}

\begin{abstract}
Profiles of ground water pesticide concentrations beneath the Nebraska Management Systems Evaluation Area (MSEA) describe the effect of $20 \mathrm{yr}$ of pesticide usage on ground water in the central Platte Valley of Nebraska. During the 6-yr (1991-1996) study, 14 pesticides and their transformation products were detected in $\mathbf{7 8 4 8}$ ground water samples from the unconfined water table aquifer. Triazine and acetamide herbicides applied on the site and their transformation products had the highest frequencies of detection. Atrazine [6-chloro- $N$-ethyl$N^{\prime}$-(1-methylethyl)-1,3,5-triazine-2,4,-diamine] concentrations decreased with depth and ground water age determined with ${ }^{3} \mathrm{H}^{3} \mathrm{He}$ dating techniques. Assuming equivalent atrazine input during the past $20 \mathrm{yr}$, the measured average changes in concentration with depth (age) suggest an estimated half-life of $>10 \mathrm{yr}$. Hydrolysis of atrazine and deethylatrazine (DEA; 2-chloro-4-amino-6-isopropylamino-s-triazine) to hydroxyatrazine [6-hydroxy- $N$-ethyl- $N^{\prime}$-(1-methylethyl)-1,3, 5-triazine-2,4-diamine] appeared to be the major degradation route. Aqueous hydroxyatrazine concentrations are governed by sorption on the saturated sediments. Atrazine was detected in the confined Ogallala aquifer in ultra-trace concentrations $\left(0.003 \mu \mathrm{g} \mathrm{L}^{-1}\right)$; however, the possibility of introduction during reverse circulation drilling of these deep wells cannot be eliminated. In fall 1997 sampling, metolachlor [2-chloro- $\mathrm{N}$-(2-ethyl-6-methylphenyl)- $\mathrm{N}$-(2-methoxy-1-methylethyl) acetamide] was detected in $57 \%$ of the 230 samples. Metolachlor oxanilic acid [(2-ethyl-6-methylphenyl) (2-methoxy-1-methylethyl) amino] oxo-acetic acid] was detected in most samples. In ground water profiles, concentrations of metolachlor ethane sulfonic acid [2-[(ethy]6-methylphenyl)(2-methoxy-1-methylethyl)amino]-2-oxo-ethanesulfonic acid] exceeded those of deethylatrazine. Alachlor [2-chloro$N$-(2,6-diethylphenyl)- $N$-(methoxymethyl)acetamide] was detected in $<\mathbf{1 \%}$ of the samples; however, alachlor ethane sulfonic acid [2-[(2,6diethylphenyl)(methoxymethyl)amino]-2-oxoethanesulfonic acid] was present in most samples $(63 \%)$ and was an indicator of past alachlor use.
\end{abstract}

$\mathrm{S}$ NCE THE DISCOVERY of atrazine in ground water overlain by irrigated row crops in central Nebraska in the late 1970s (Spalding et al., 1980), more than 139 pesticide residues and 23 transformation products have been reported in the ground water of the United States (Barbash and Resek, 1996). Triazine and acetamide herbicides are the most frequently reported pesticides in ground water in corn [Zea mays L.] and soybean [Glycine $\max$ (L.) Merr.] growing areas (Spalding et al., 1989; Roux et al., 1991; Kolpin et al., 1996; Barbash et al., 1999). The high frequency of detection is due to a combination of their high use on these commodities and

R.F. Spalding and D.D. Snow, Dep. of Agronomy and Horticulture, Univ. of Nebraska, Lincoln, NE 68583-0915. M.E. Exner, School of Natural Resource Sciences, Univ. of Nebraska, Lincoln, NE 685830759. D.A. Cassada, M.E. Burbach, and S.J. Monson, Water Sciences Laboratory, Univ. of Nebraska, Lincoln, NE 68583-0844. Received 20 Feb. 2002. *Corresponding author (rspalding1@unl.edu).

Published in J. Environ. Qual. 32:92-99 (2003). physical-chemical characteristics that allow for mobility and moderate persistence. Atrazine, the most widespread pesticide in the nation's ground water, and its transformation products together with cyanazine, simazine, and alachlor and metolachlor and their transformation products are the most commonly detected herbicides in row-cropped regions (Barbash et al., 1999) (see Table 1 for chemical names of pesticides detected in this study).

National or regional assessments of pesticide concentrations in ground water link most detections and frequency of occurrence of specific pesticides to high-use areas and the chemical properties of the compound (Klaseus et al., 1988; Exner and Spalding, 1990; Kross et al., 1990; USEPA, 1990; Roux et al., 1991; Holden et al., 1992; Kolpin, 1997; Ator and Ferrari, 1997; Kolpin et al., 2000). Even in high-use areas most pesticide concentrations in ground water are at sub-part per billion concentrations $\left(\mu \mathrm{g} \mathrm{L}^{-1}\right)$ with only a handful having concentrations consistently near or exceeding $1 \mu \mathrm{g} \mathrm{L}-1$. The USEPA has set maximum contaminant levels (MCLs) for atrazine, alachlor, and simazine in drinking water (Table 1).

The presence of transformation products was ignored for two decades largely because the focus was pesticides with regulated concentrations in drinking water, and because methods for their analysis needed to be developed and tested. In surveys conducted in agricultural regions during the early and mid-1990s, transformation products, not parent compounds, were the most frequently detected pesticide compounds (Kolpin et al., 1995; Potter and Carpenter, 1995). Especially prevalent in ground water are the two triazine metabolites deethylatrazine (DEA) and deisopropylatrazine (DIA), which frequently are quantified in the same analytical scheme as atrazine and the acetamide herbicides. The recent development of analytical methods for the ethane sulfonic acid (ESA) and oxanilic acid (OA) metabolites of alachlor, metolachlor, acetochlor, and propachlor (Ferrer et al., 1997) have led to the widespread detection of these metabolites in ground water in regional surveys (Kalkhoff et al., 1998). Understanding the fate of herbicides in ground water is intrinsically related to the quantification of their major transformation products.

The 6-yr study at the Nebraska MSEA, one of five USDA-sponsored MSEA projects in five midwestern states in the corn and soybean belt, evaluated the effect of four nutrient and four irrigation practices on nitrate

Abbreviations: DDA, didealkylatrazine; DEA, deethylatrazine; DIA,
deisopropylatrazine; ESA, ethane sulfonic acid; HA, hydroxyatrazine;
MLS, multilevel sampler; MSEA, Management Systems Evaluation Area; OA, oxanilic acid. 
loading in a shallow unconfined aquifer (Spalding et al., 2001). A comparison of the effects of precipitation and irrigation on atrazine, the atrazine metabolites DEA and DIA, and metolachlor loading showed that peak atrazine and metolachlor loading was more dependent on focused recharge from sites where storm water ponded in cropped fields and road ditches than from infiltration from less disturbed parts of the fields (Spalding et al., 2003). The objectives of this paper are to describe the distribution of herbicide and transformation product concentrations in the shallow unconfined water table aquifer and in the deeper confined Ogallala aquifer beneath the Nebraska MSEA. The data for the concentration profiles were obtained from a network of multilevel ground water samplers in an unconfined, predominately sand and gravel aquifer.

\section{MATERIALS AND METHODS Study Site}

The Nebraska MSEA site is located in central Nebraska approximately $6 \mathrm{~km}$ north of the Platte River (Fig. 1). Regional ground water quality, site selection, and site layout are discussed in Spalding et al. (2001, 2003).

\section{Hydrogeology and Water Quality}

The unsaturated zone of the research-demonstration site is a 1.1-m-thick, well-drained, silt loam overlaying $4.3 \mathrm{~m}$ of fine to medium-textured sands. The well-drained Hord silt loam (fine-silty, mixed, mesic Cumulic Haplustoll) is the predominant soil and there are small areas of Hall silt loam (finesilty, mixed, mesic Pachic Argiustoll). Quaternary-age sands and gravels form the 14.3- to 17.3-m-thick shallow water table aquifer that overlies a 9- to 20-m-thick clayey silt aquitard that separates the unconfined water table aquifer and the confined Ogallala aquifer (Diffendal and Smith, 1996). Both aquifers serve as drinking water supplies for area residents.

Annual precipitation, depth to water, hydraulic conductivities, and estimated nonretarded transport times across the Nebraska MSEA are described in Spalding et al. (2001). Ground water in the unconfined water table aquifer was successfully dated in 1993 (Spalding et al., 2001) with atmospherically derived tritium $\left({ }^{3} \mathrm{H}\right)$ and stable daughter $\left({ }^{3} \mathrm{He}\right)$ procedures.

Baseline water quality data were obtained for both aquifers in 1990. The unconfined aquifer was initially monitored at an 11-multilevel sampler (MLS) network installed within the research-demonstration site and the upgradient buffer. These data were used to optimize the locations of 31 permanent MLSs. Atrazine concentrations averaged $2.1 \pm 1.3 \mu \mathrm{g} \mathrm{L}^{-1}$ in the unconfined aquifer. Deethylatrazine $\left(0.90 \pm 0.29 \mu \mathrm{g} \mathrm{L}^{-1}\right)$, DIA $\left(0.02 \pm 0.03 \mu \mathrm{g} \mathrm{L}^{-1}\right)$, propazine $\left(0.00 \pm 0.01 \mu \mathrm{g} \mathrm{L}^{-1}\right)$, and metolachlor $\left(0.03 \pm 0.10 \mu \mathrm{g} \mathrm{L}^{-1}\right)$ also were detected in the unconfined aquifer.

Three wells in the Ogallala aquifer were sampled to characterize the quality of the confined aquifer. Pesticides were not detected in the confined aquifer with routine analytical procedures. Dissolved organic carbon concentrations averaged $3.3 \pm 0.3 \mathrm{mg} \mathrm{C} \mathrm{L}^{-1}$ and $0.6 \pm 0.1 \mathrm{mg} \mathrm{C} \mathrm{L}^{-1}$ in the unconfined and confined aquifers, respectively, and were consistent with values reported $20 \mathrm{yr}$ ago (Spalding et al., 1978). Average $\mathrm{pH}$ values in the unconfined and confined aquifers were $6.8 \pm$ 0.3 and $6.7 \pm 0.0$, respectively.

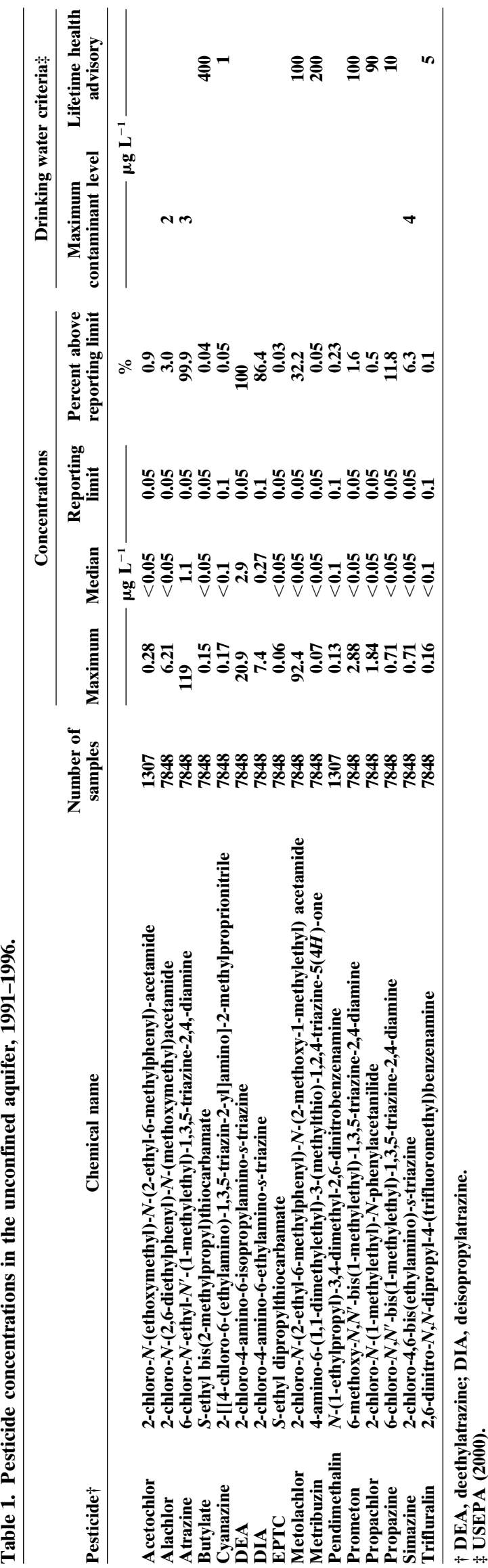




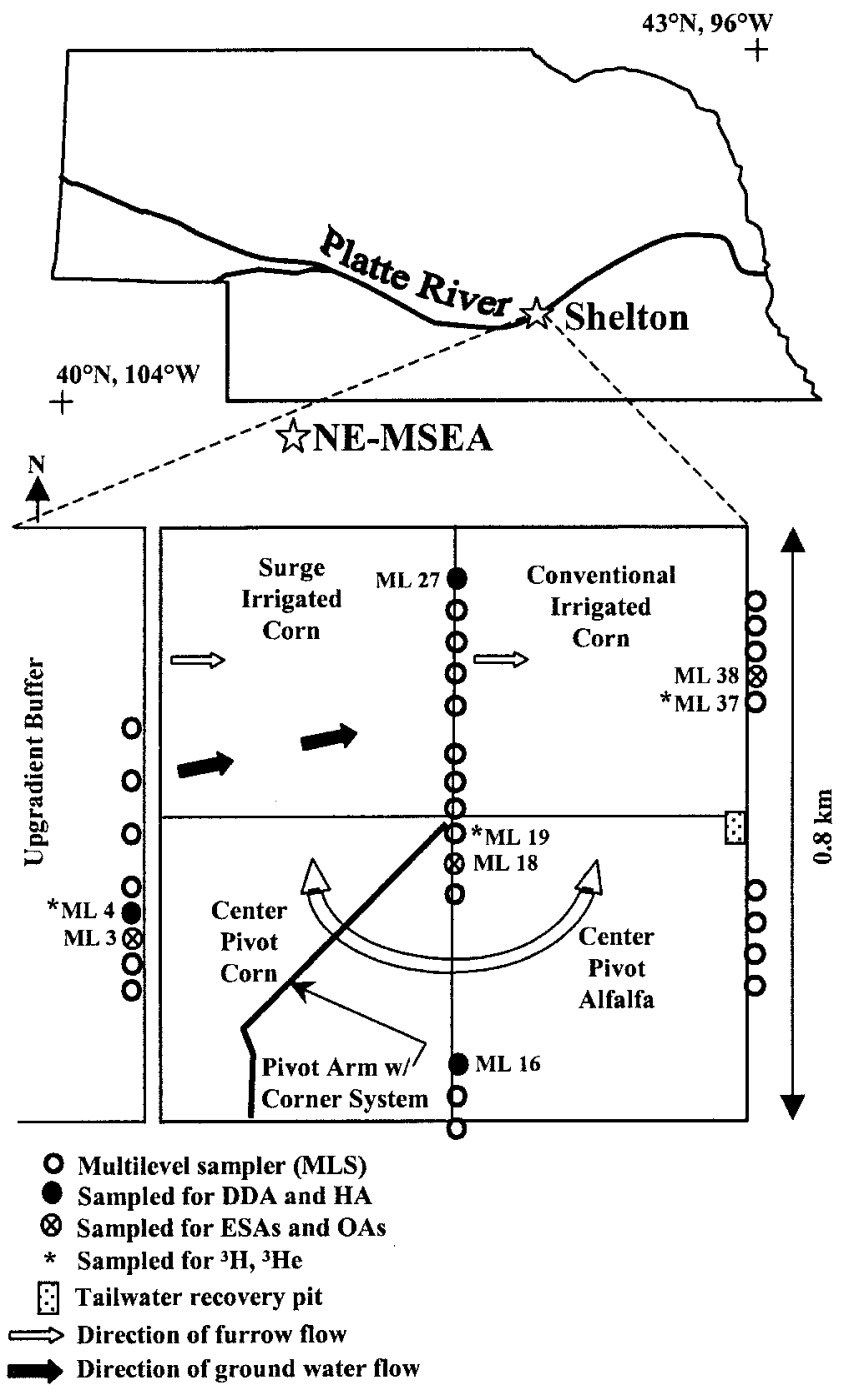

Fig. 1. Location of the Nebraska Management Systems Evaluation Area (MSEA) and layout of research-demonstration site and sampling locations.

\section{Study Design}

The 54-ha research-demonstration site was subdivided into four 13.4-ha management fields (Fig. 1). Three fields were cropped to corn and the fourth to alfalfa (Medicago sativa L.). In keeping with the local practice of banding preemergent herbicides at planting, each corn management field received 46-cm-wide banded applications containing $1.68 \mathrm{~kg}$ atrazine $\mathrm{ha}^{-1}$ and $0.75 \mathrm{~kg}$ metolachlor ha ${ }^{-1}$ as Bicep (Sygenta Crop Protection, Greensboro, NC) between April 29 and May 20. Although the site reverted to farmer-landowner management after the 1996 growing season, no changes were made in the herbicide treatment or irrigation practices at the four management fields during 1997 (Spalding et al., 2001).

The unconfined aquifer was sampled with the 31 MLSs shown in Fig. 1. Each MLS was designed so that ground water could be obtained from as many as 16 depths. Most MLSs consisted of 8 stainless steel gas-drive samplers, 16 low-density polyethylene (LDPE) suction sampling tubes, and 4 PVC piezometers. The rationale for the design and the construction details are given in Spalding et al. (2001).

Using specially constructed MLSs at the research-demonstration site, Papiernik et al. (1996) showed the tubing com- position (polytetrafluoroethylene, rigid polyvinyl chloride, stainless steel, LDPE, and high-density polyethylene) of the samplers did not significantly affect the aqueous concentrations of atrazine and its transformation products, DEA and DIA, butachlor [2-chloro-2', $6^{\prime}$-diethyl- $N$-(butoxymethyl) acetanilide], metolachlor, alachlor, and cyanazine. Ground water for herbicide analyses was obtained from the LDPE suction sampling tubes and the herbicide concentrations are representative of aquifer concentrations. The effect of tubing composition on the concentrations of the other pesticides addressed in this paper could not be evaluated as the concentrations were at or below the limits of detection.

From 1991 through 1997 samples were collected three times a year: in late March during the preplant period, in late June prior to irrigation season, and in early October after irrigation and harvest. All MLSs were sampled through 1996 with a smaller subset sampled in 1997. Field methods, water table measurements, and sample collection procedures are detailed in Spalding et al. (2003).

Three deep boreholes were drilled into the confined Ogallala aquifer to about $40 \mathrm{~m}$ with reverse circulation and were cased with 10.2-cm-diameter polyvinyl chloride (PVC). The annular space at the screens was gravel packed, and bentonite slurry was pumped into the annular space from the water table to the top of the screen to provide a seal.

\section{Analytical Methods}

Atrazine, DEA, DIA, alachlor, metolachlor, and 11 additional pesticides (Table 1) were quantified with the stable isotope dilution method described in Cassada et al. (1994). The detection limit for each analyte was determined by the standard deviation method with eight fortified samples (USEPA, 1989). Quality assurance-quality control (QA-QC) protocol included the analysis of one field duplicate, field blank, laboratory fortified blank, laboratory fortified matrix, and laboratory reagent sample for every 20 field samples. The reporting limit (Table 1) for each analyte ranged from two to three times the detection limit, thereby increasing confidence in the results.

Atrazine was quantified in samples from the Ogallala aquifer with ${ }^{13} \mathrm{C}_{3}$-labeled atrazine as an internal standard and high resolution mass spectrometry (MS) (Cai et al., 1993). The method detection limit was $0.50 \mathrm{ng} \mathrm{L}^{-1}$ and the precision was $\pm 15 \%$ for water samples containing $1 \mathrm{ng} \mathrm{L}^{-1}$.

Parts per trillion $\left(\mathrm{ng} \mathrm{L}^{-1}\right)$ residues of hydroxyatrazine (HA) were measured by the method of Cai et al. (1994). Samples were analyzed by fast atom bombardment high resolution MS and quantified with ${ }^{13} \mathrm{C}_{3}$-labeled HA. The method detection limit was $1.3 \mathrm{ng} \mathrm{L}^{-1}$ and the precision was $\pm 10 \%$ as measured in a $10 \mathrm{ng} \mathrm{L}^{-1}$ fortified water sample.

Didealkylatrazine (DDA; 2-chloro-4,6-diamino-s-triazine) in $200 \mathrm{~mL}$ of sample was sorbed to graphitized carbon black and quantified with high resolution MS (Cai et al., 1995). The detection limit was $3 \mathrm{ng} \mathrm{L}^{-1}$ and the precision was $\pm 20 \%$. Previously published DDA concentrations in natural waters relied upon $\mathrm{C}_{18}$ solid phase extraction and mass selective detector quantification; however, the recoveries were poor (Mills and Thurman, 1994).

The ethane sulfonic acid (ESA) and oxanilic acid (OA) metabolites of acetochlor, alachlor, and metolachlor were concentrated by solid phase extraction and quantified with liquid chromatography-mass spectrometry (LC-MS) and LC-MSMS (Ferrer et al., 1997; Vargo, 1998). Since these metabolites are not commercially available, several neat ESA standards were synthesized following the method of Feng (1991) while others were obtained from Monsanto (St. Louis, MO) and 
Novartis (Greensboro, NC). Known amounts of butachlor ESA [2-[(2,6-diethylphenyl)(1-butoxymethyl)amino]-2-oxo-ethane sulfonic acid] (internal standard) and pretilachlor ESA [2-[(2, 6-diethylphenyl)(2-propoxyethyl)amino]-2-oxo-ethane sulfonic acid] and dimethachlor ESA [2-[(2,6-dimethylphenyl)(2-methoxyethyl)amino]-2-oxo-ethane sulfonic acid] (surrogate compounds) were added to each 100-mL sample prior to extraction. The compounds were extracted with a preconditioned 1-g trifunctional $\mathrm{C}_{18}$ solid phase extraction cartridge, eluted with $2 \mathrm{~mL}$ of methanol, and concentrated to approximately $200 \mu \mathrm{L}$ by evaporation. Analytes were separated and quantified with a Finnigan LCQ ion trap mass spectrometer (Finnigan Thermoquest, San Jose, CA) equipped with an electrospray ionization source operated in the negative ion mode. Compound identification was based upon the occurrence of each compound's product ion at the proper retention time, a technique that is especially important for the identification of alachlor and acetochlor ESA metabolites (Vargo, 1998). Quantitation was based on the target compound's response relative to that of the internal standard. Method detection limits determined from $100-\mathrm{mL}$ fortified samples were near $0.05 \mu \mathrm{g} \mathrm{L}^{-1}$ and reporting limits were $0.1 \mu \mathrm{g} \mathrm{L}^{-1}$.

\section{RESULTS AND DISCUSSION}

\section{Detected Pesticides}

Fourteen pesticide active ingredients and two transformation products (Table 1) were detected in the unconfined aquifer beneath the research-demonstration site from 1991 through 1996. Atrazine and DEA concentrations were detected in 99.9 and $100 \%$, respectively, of the 7848 samples. Deisopropylatrazine was detected in $86.4 \%$ of the samples. Average DIA concentrations were 10 times less than those of DEA. Atrazine, DEA, and DIA concentrations were at or above the reporting limit in all samples; however, atrazine concentrations remained below the $3 \mu \mathrm{g} \mathrm{L}^{-1}$ maximum contaminant level. The incidence of detection of metolachlor $(32.2 \%)$ was considerably less than that of atrazine and its primary metabolites. Prior to 1992 only a few samples $(9.8 \%)$ had metolachlor concentrations above the reporting limit. While metolachlor and atrazine were applied to the site annually between 1991 and 1996, metolachlor was not applied prior to 1991. Atrazine, however, had been applied to the site for nearly three decades and reportedly had been used at higher rates during the 1970s and early 1980s.

Propazine $(11.8 \%)$, simazine $(6.3 \%)$, alachlor $(3 \%)$, and prometon $(1.6 \%)$ were also detected in the unconfined aquifer. There is no history of propazine use at the site; however, atrazine formulations, which should be $92 \%$ pure and usually are $95 \%$ pure (Health and Safety Guide, 1990), contain the impurities sodium chloride, simazine, and propazine. Atrazine to propazine ratios in the samples indicated that the atrazine formulations contained 1 to $3 \%$ propazine. Simazine reportedly was also used for broadleaf weed control in the shelterbelt along the southern border of the site (L. Niemack, personal communication, 1991). Alachlor was applied to the site prior to 1990 . Prometon occurrence is very widespread in the hydrologic system and in the ground water at the site may originate from nonagricultural uses, such as applications to driveways and fence lines (Capel et al., 1999).

The detection frequencies of cyanazine $(0.1 \%)$ and metribuzin $(0.1 \%)$, pesticides that were applied to cropland in the region but were not applied to the Nebraska MSEA, were very low. Acetochlor, measured only in 1996, was detected in the summer in ML 34. It is not known whether the acetochlor, which was not applied to the site, originated from a spill along the fence row or from runoff from the corn field to the east. Trace concentrations of pendimethalin and trifluralin in a few samples may be false positives. According to Martin (1999), both compounds are likely to be falsely quantified near the method detection limit. Both have very high organic carbon partition coefficients, and transport through the unsaturated zone to the ground water is unlikely.

\section{Ground Water Ages and Concentration Profiles}

Ground water collected at three MLSs across the site in spring 1993 (Fig. 1) was dated with ${ }^{3} \mathrm{H} /{ }^{\beta} \mathrm{He}$ (Spalding et al., 2001). The ${ }^{3} \mathrm{H} /{ }^{3} \mathrm{He}$ clock starts at or near the water table. Ages ranged from $0.0 \pm 0.5 \mathrm{yr}$ at the surface to approximately $20 \mathrm{yr}$ at the bottom of the unconfined aquifer. Ages were consistently older with depth and for equivalent depths were quite consistent across the site. Using ground water ages and nitrate concentrations, Spalding et al. (2001) showed that seasonal changes in nitrate concentrations in the uppermost $1.5 \mathrm{~m}$ of the unconfined aquifer could be conservatively attributed to loading during the preceding months. The residence times for water at depths greater than approximately $5 \mathrm{~m}$ below the water table were greater than $5 \mathrm{yr}$ and indicate water that is transported horizontally from upgradient of the site.

During the investigation atrazine and DEA concentrations beneath the corn management fields were lower and remained relatively constant in the older, deeper ground water $(>7 \mathrm{yr}$ old and $>6 \mathrm{~m}$ below the water table) (Fig. 2b) compared with those in the uppermost ground water (approximately $1 \mathrm{yr}$ old and $\leq 1.5 \mathrm{~m}$ below the water table) (Fig. 2a). Average DEA concentrations of $2.4 \mu \mathrm{g} \mathrm{L}^{-1}$ were $1.1 \mu \mathrm{g} \mathrm{L}^{-1}$ higher than those of atrazine. Metolachlor was detected at concentrations above the reporting limit at only two depths greater than $6 \mathrm{~m}$. The results indicate that during the 6 -yr study the deeper, older ground water remained isolated and was not affected by annual contaminant loading events.

Prior to the 1993 corn planting there was commonality in the concentration profiles of atrazine, its transformation products DEA, DIA, DDA, and HA, and metolachlor at three locations (Fig. 3). The atrazine, DEA, DIA, and metolachlor concentration profiles at the other 28 MLSs had patterns similar to those shown in Fig. 3. Analysis of DDA and HA was limited to these three profiles. Generally herbicide and transformation product concentrations decreased with depth and aquifer residence time, as indicated by the ground water age, in the unconfined aquifer. Throughout the unconfined aquifer, DEA concentrations were almost double those 


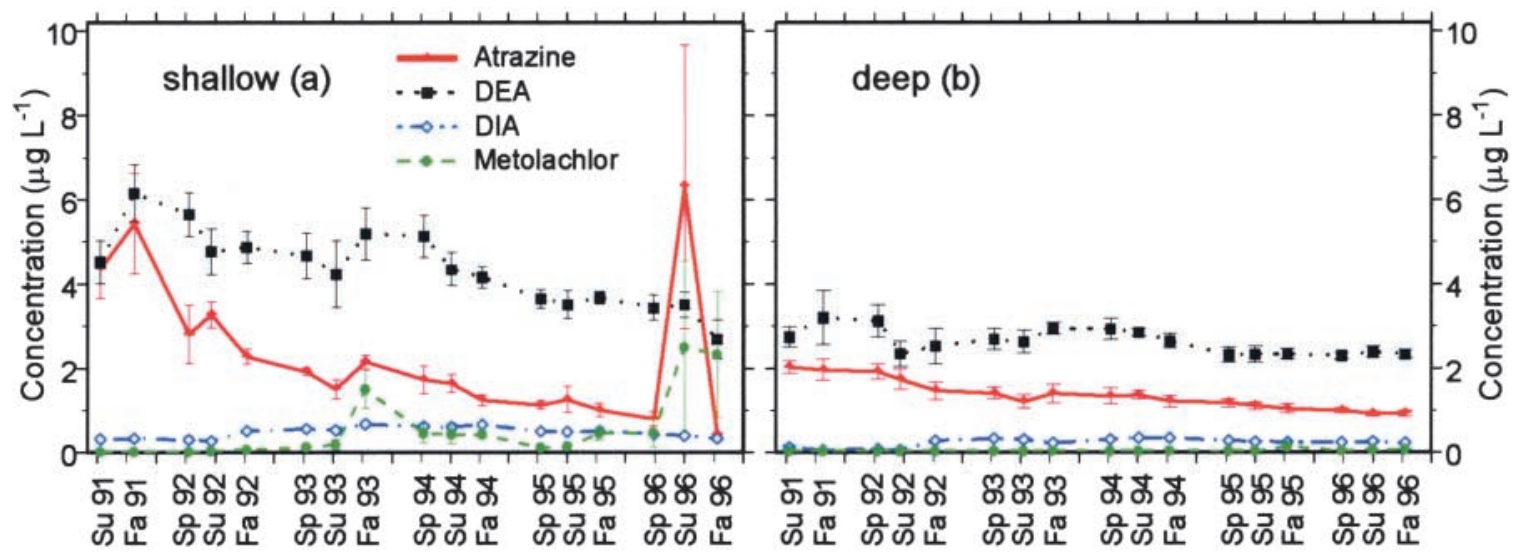

Fig. 2. Atrazine, atrazine transformation products (DEA, deethylatrazine; DIA, deisopropylatrazine), and metolachlor concentrations in the ( $a$ ) shallow $(\leq 1.5 \mathrm{~m})$ and $(b)$ deep $(>6 \mathrm{~m})$ ground water of the unconfined aquifer downgradient of the corn management fields.

of atrazine and DEA was the dominant atrazine species in the ground water. The DIA concentrations were $<1.0$ $\mu \mathrm{g} \mathrm{L}^{-1}$ and generally followed the DDA profile in the bottom two-thirds of the unconfined aquifer. The DDA concentrations in the upper $2 \mathrm{~m}$ of the aquifer were approximately $1 \mu \mathrm{g} \mathrm{L}^{-1}$ and decreased to approximately $0.20 \mu \mathrm{g} \mathrm{L}^{-1}$ at depths greater than $10 \mathrm{~m}$. While DDA is a commonly reported transformation product in ground water beneath high simazine use areas in California (Troiano et al., 2001), DDA is rarely reported in $\mathrm{Ne}$ braska and Iowa where atrazine is the dominant herbicide (Kolpin et al., 2000). The very low HA concentrations ranged from 0.011 to $0.030 \mu \mathrm{g} \mathrm{L}^{-1}$ and decreased with depth.

The high correlation $(r=0.73)$ of DEA and atrazine concentrations in the three profiles (Fig. 3) indicated that approximately $50 \%$ of the DEA variability was associated with atrazine. This association and the trend of decreasing atrazine and DEA concentrations with depth from 1991 through spring 1993 suggested two scenarios: (i) there was progressively less loading of atrazine and DEA with increasing distance upgradient of the site or (ii) atrazine and DEA were transformed in the ground water at approximately the same rate. The first scenario is highly unlikely as the upgradient fields have been cropped fence-row-to-fence-row with irrigated corn and treated with atrazine for at least the last quarter-century. Rather, it is more probable that intrinsic remediation by abiotic transformation reduced the concentrations of atrazine and DEA to hydroxytriazines. The half-life of parent and primary transformation product in the aquifer appears to range from 10 to $20 \mathrm{yr}$.

Low HA concentrations ranging from 10 to $30 \mathrm{ng} \mathrm{L}^{-1}$ in the unconfined aquifer were apparently controlled by HA partitioning to the primarily sandy, silty, and gravelly aquifer materials. The major transformation product of atrazine in sandy loams (Sorenson et al., 1993), HA has been shown to tightly bond to soils (Clay and Koskinen, 1990; Lerch et al., 1996). Sorptive loss of aqueous concentrations of HA was supported by a laboratory experiment in which $80 \%$ of the HA spiked into an 80:20 water and Nebraska MSEA aquifer sediment (sand and gravel) mixture was removed from the water phase after $3 \mathrm{~min}$ of manual shaking. Highest HA concentrations in the shallowest ground water may suggest that HA production is concentration dependent.

Atrazine was detected in the confined Ogallala aquifer at concentrations of $0.003 \mu \mathrm{g} \mathrm{L}^{-1}$. Despite lengthy pumping during well development to remove drilling fluids, the introduction of atrazine during well drilling that relied heavily on the use of water cannot be ruled out. No other pesticides or transformation products were measured in samples from the Ogallala aquifer with this degree of sensitivity.

\section{Metolachlor and Alachlor Transformation Products}

To better elucidate the fate of metolachlor and alachlor in ground water, metolachlor and alachlor ESA and OA transformation products were quantified in more than 230 fall 1997 samples from selected MLSs. Metolachlor was detected in $57 \%$ of the samples and concentrations ranged as high as $6.7 \mu \mathrm{g} \mathrm{L}^{-1}$. Metolachlor ESA and OA were detected in 99 and $35 \%$ of the samples, respectively, with maximum concentrations of 24 and $3.8 \mu \mathrm{g} \mathrm{L}^{-1}$, respectively. Alachlor, which had not been applied to the site since 1989 , was detected in only two samples $(<1 \%)$ while alachlor ESA was detected in $63 \%$ of the samples at concentrations as high as 4.5 $\mu \mathrm{g} \mathrm{L}^{-1}$. Alachlor OA was detected in only one sample $\left(0.3 \mu \mathrm{g} \mathrm{L} \mathrm{L}^{-1}\right)$.

Metolachlor ESA concentrations in the unconfined aquifer averaged $5.8 \mu \mathrm{g} \mathrm{L}^{-1}$ in the shallow water $(\leq 1.5 \mathrm{~m}), 4.8 \mu \mathrm{g} \mathrm{L}^{-1}$ at mid-depths, and $2.1 \mu \mathrm{g} \mathrm{L}^{-1}$ in the bottom third of the aquifer. In comparison, alachlor ESA concentrations were lower and varied less with depth with average concentrations of $0.45 \mu \mathrm{g} \mathrm{L}^{-1}$ in the shallow ground water, $0.62 \mu \mathrm{g} \mathrm{L}^{-1}$ at mid-depths, and $0.50 \mu \mathrm{g} \mathrm{L}^{-1}$ in the bottom third of the aquifer. Representative vertical profiles from three locations across the site (Fig. 4) indicate that in fall 1997 metolachlor ESA contributed more mass than any other pesticide monitored in the underlying ground water. Throughout most of the profile, metolachlor ESA concentrations greatly exceeded those of metolachlor by factors of approxi- 

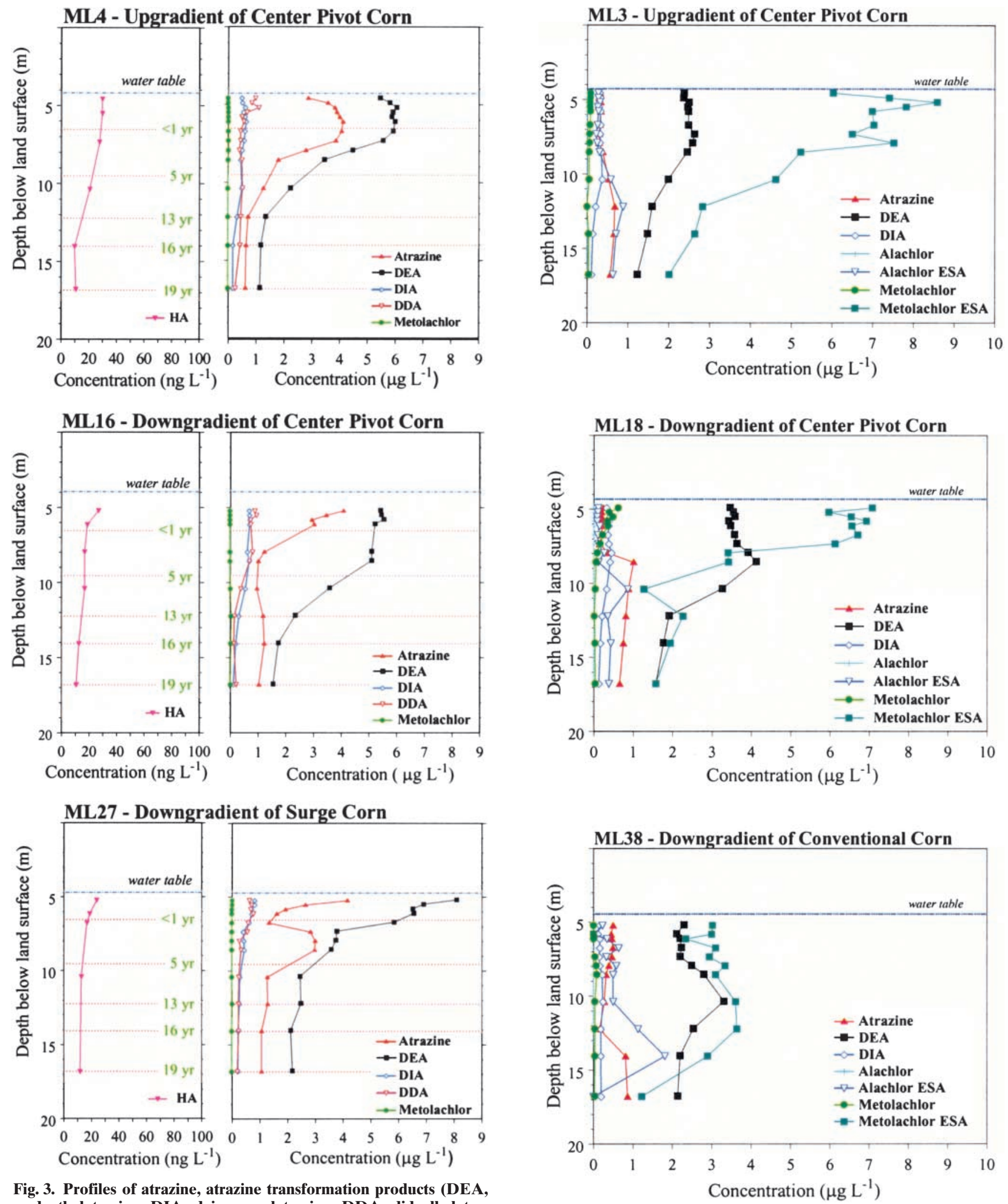

Fig. 3. Profiles of atrazine, atrazine transformation products (DEA, deethylatrazine; DIA, deisopropylatrazine; DDA, didealkylatrazine), and metolachlor in the unconfined aquifer and ground water ages, spring 1993. [Ages are from Spalding et al. (2001).]

Fig. 4. Profiles of commonly detected triazine and acetamide herbicides and their metabolites in the unconfined aquifer, fall 1997. DEA, deethylatrazine; DIA, deisopropylatrazine; ESA, ethane sulfonic acid. 
mately 10 to approximately 100. Aga et al. (1996) reported that as metolachlor degraded in Kansas soils, concentrations of its ESA metabolite increased for about $100 \mathrm{~d}$ and then decreased. The subsequent decrease in ESA soil concentrations was attributed to leaching below the soil horizons sampled in their study. Ethane sulfonic acid compounds are ionized in soil and water and thus are extremely mobile. Field and Thurman (1996) suggested that ESA formation could also occur in shallow ground water. High ESA metabolite to parent ratios at the Nebraska MSEA site concur with those reported by Ferrer et al. (1997) and Kalkhoff et al. (1998) in Iowa ground water surveys and further indicate that metolachlor ESA is much more pervasive and persistent in ground water than its parent herbicide.

The uniform alachlor ESA concentrations (approximately $0.1 \mu \mathrm{g} \mathrm{L}^{-1}$ ) in the shallow ground water of the profiles suggest relatively continuous low-level leaching from the unsaturated zone. Higher concentrations in the mid-depth ground water appear correlated with past use on upgradient fields during the 1980s. Kolpin et al. (1996) reported that alachlor ESA was the most frequently detected pesticide in ground water of the north-central corn-producing region of the USA; however, metolachlor ESA was not measured in the ground water profile. Rapid transformation of alachlor in soils and slow transformation in saturated conditions (Potter and Carpenter, 1995; Kolpin et al., 1996) suggest that most degradation occurs in the soils. A glutathione conjugation process in terrestrial microorganisms is believed to form the sulfonated metabolite (Laue et al., 1996). The higher alachlor ESA concentrations in the deep ground water indicate that this highly mobile compound is very persistent and in all probability has a half-life in ground water greater than the 10 to $20 \mathrm{yr}$ estimated for atrazine. The absence of detectable concentrations of alachlor OA in all but one sample indicates that it degrades more quickly than metolachlor OA. Acetochlor ESA [2-[(ethyl-6-methylphenyl)(ethoxymethyl)amino]-2-oxo-ethanesulfonic acid] was not detected in any of the samples.

\section{CONCLUSIONS}

Fourteen pesticides and transformation products were detected in the unconfined aquifer during the 6-yr $\mathrm{Ne}$ braska MSEA study. Herbicides applied to the Nebraska MSEA and their transformation products had the highest frequencies of detection. Common pesticide impurities, such as propazine and simazine, were also routinely detected.

Atrazine concentrations were stratified during the first years of the study with highest levels in the shallow ground water and lowest levels at the bottom of the unconfined aquifer. The combination of ground water ages and declines in atrazine concentration with depth allowed estimation of a 10 to $20 \mathrm{yr}$ half-life for atrazine. Atrazine appears to be slowly transformed by hydrolysis to hydroxyatrazine, which is present in trace concentrations because its aqueous concentration is governed by partitioning to the aquifer solids. Atrazine was detected in the confined Ogallala aquifer in ultra-trace concentrations $\left(<0.01 \mu \mathrm{g} \mathrm{L}^{-1}\right)$; however, its introduction during monitoring well drilling is a distinct possibility. The data vividly demonstrate the difficulty in assigning origins to ultra-trace levels of pesticides in deep wells requiring drilling fluid circulation during construction.

The atrazine transformation products DEA, DIA, and DDA were also detected in the unconfined aquifer. On average, DEA concentrations exceeded those of atrazine by a factor of approximately two. Deisopropylatrazine and DDA are not preferred transformation products in the soil metabolism of atrazine and were detected in the ground water mostly in sub-microgram per liter concentrations.

Acetamide ESAs and OAs were added to the normal suite of pesticides in 1997. Metolachlor ESA was detected in $99 \%$ of the 230 samples analyzed at concentrations that exceeded those of the other detected transformation products and parent compounds. Metolachlor OA was detected in considerably fewer samples than its ESA. Presumably, metolachlor ESA is the preferred transformation product or it is more persistent than metolachlor OA. Alachlor ESA, which was detected in $63 \%$ of the samples, tended to have peak concentrations at the mid-aquifer depths, suggesting infiltration from upgradient fields during the years of heavy alachlor usage during the 1980s. Only two samples contained alachlor, indicating that almost all the residual alachlor has been transformed. Alachlor OA was detected in only one sample.

\section{ACKNOWLEDGMENTS}

The authors are grateful to Jeff Toavs and Tom Papiernik for assistance in the installation and sampling of the MLSs. The project was funded by USDA-CSRS. The Water Sciences Laboratory received support from the Nebraska Research Initiative. The acetamide transformation product sampling and analysis were funded by the Nebraska Department of Agriculture and the Central Platte Natural Resources District. The authors are deeply indebted to Loran Niemack, the cooperating farmer. This manuscript has been assigned Journal Series no. 13733, Agricultural Research Division, University of Nebraska.

\section{REFERENCES}

Aga, D.S., E.M. Thurman, M.E. Yockel, L.R. Zimmerman, and T.D. Williams. 1996. Identification of a new sulfonic acid metabolite of metolachlor in soil. Environ. Sci. Technol. 30:592-597.

Ator, S.W., and M.J. Ferrari. 1997. Nitrate and selected pesticides in the mid-Atlantic region. Water Resour. Investigations Rep. 974139. U.S. Geol. Survey, Reston, VA.

Barbash, J.E., and E.A. Resek. 1996. Pesticides in ground water. Distributions, trends, and governing factors. Ann Arbor Press, Chelsea, MI.

Barbash, J.E., G.P. Thelin, D.W. Kolpin, and R.J. Gilliom. 1999. Distribution of major herbicides in ground water of the United States. Water Resour. Investigations Rep. 98-4245. U.S. Geol. Survey, Reston, VA.

Cai, Z., M.L. Gross, and R.F. Spalding. 1995. Determination of didealkylatrazine in water by graphatized carbon black extraction followed by gas chromatography/high resolution mass spectrometry. Anal. Chim. Acta 304:67-73.

Cai, Z., V.M. Sadagopa Ramanujam, D.E. Giblin, M.L. Gross, and R.F. Spalding. 1993. Determination of atrazine in water at lowand sub-parts-per-trillion levels by using solid-phase extraction and 
gas chromatography/high resolution mass spectrometry. Anal. Chem. 54(1):21-26.

Cai, Z., V.M. Sadagopa Ramanujam, M.L. Gross, S.J. Monson, D.A. Cassada, and R.F. Spalding. 1994. Liquid-solid extraction and fast atom bombardment high-resolution mass spectrometry for the determination of hydroxyatrazine in water at low-ppt levels. Anal. Chem. 66:4202-4209.

Capel, P.D., A.H. Spexet, and S.J. Larson. 1999. Occurrence and behavior of the herbicide prometon in the hydrologic system. Environ. Sci. Technol. 33(5):674-680.

Cassada, D.A., R.F. Spalding, Z. Cai, and M.L. Gross. 1994. Determination of atrazine, deethylatrazine, and deisopropylatrazine in water and sediment by isotope dilution gas chromatography-mass spectrometry. Anal. Chim. Acta 287:7-15.

Clay, S.A., and W.C. Koskinen. 1990. Adsorption and desorption of atrazine, hydroxyatrazine, and s-glutathione in soils. Weed Sci. 38 : 262-266.

Diffendal, R.F., and F.A. Smith. 1996. Geology beneath the primary Management Systems Evaluation Area (MSEA) site southwest of Shelton, Buffalo County, Nebraska. Nebraska Geol. Survey Rep. Invest. no. 11. Conserv. and Survey Div., Univ. of Nebraska, Lincoln.

Exner, M.E., and R.F. Spalding. 1990. Occurrence of pesticides and nitrate in Nebraska ground water. Water Center Publ. 1. Water Center, Inst. of Agric. and Natural Resour., Univ. of Nebraska, Lincoln.

Feng, P.C.C. 1991. Soil transformation of acetochlor via glutathione conjugation. Pestic. Biochem. Physiol. 40:136-142.

Ferrer, I., E.M. Thurman, and D. Barcelo. 1997. Identification of ionic chloroacetanilide-herbicide metabolites in surface water and groundwater by HPLC/MS using negative ion spray. Anal. Chem. 69:4547-4553.

Field, J.A., and E.M. Thurman. 1996. Glutathione conjugation and contaminant transformation. Environ. Sci. Technol. 30:1413-1418.

Health and Safety Guide. 1990. International programme on chemical safety. Atrazine health and safety guide. Available online at http:// www.inchem.org/documents/hsg/hsg/hsg047.htm (verified $12 \mathrm{Sept}$ 2002). Int. Programme on Chemical Safety.

Holden, L.R., J.A. Graham, R.W. Whitmore, W.J. Alexander, R.W. Pratt, S.K. Liddle, and L.L. Piper. 1992. Results of the national alachlor well water survey. Environ. Sci. Technol. 26:935-943.

Kalkhoff, S.J., D.W. Kolpin, E.M. Thurman, I. Ferrer, and D. Barcelo. 1998. Degradation of chloroacetanilide herbicides: The prevalence of sulfonic and oxanilic acid metabolites in Iowa groundwaters and surface waters. Environ. Sci. Technol. 32:1738-1740.

Klaseus, T.G., G.C. Buzicky, and E.C. Schneider. 1988. Pesticides and ground water: Surveys of selected Minnesota wells. Rep. to the Legislative Commission on Minnesota Resources. Minnesota Dep. of Health and Minnesota Dep. of Agric., St. Paul.

Kolpin, D.W. 1997. Agricultural chemicals in groundwater of the Midwestern United States: Relations to land use. J. Environ. Qual. 26:1025-1037.

Kolpin, D.W., J.E. Barbash, and R.J. Gilliom. 2000. Pesticides in ground water of the United States, 1992-1996. Ground Water 38: 858-863.

Kolpin, D.W., D.A. Goolsby, and E.M. Thurman. 1995. Pesticides in near-surface aquifers: An assessment using highly sensitive analytical methods and tritium. J. Environ. Qual. 24:1125-1132.

Kolpin, D.W., E.M. Thurman, and D.A. Goolsby. 1996. Occurrence of selected pesticides and their metabolites in near-surface aquifers of the Midwestern United States. Environ. Sci. Technol. 30:335340.

Kross, B.C., G.R. Hallberg, D.R. Bruner, R.D. Libra, K.D. Rex,
L.M.B. Weish, M.E. Vermace, L.F. Burmeister, N.H. Hall, K.L. Cherryholmes, J.K. Johnson, M.I. Selim, B.K. Nations, L.S. Seigley, D.J. Quade, A.G. Dudler, K.D. Sesker, M.A. Culp, C.F. Lynch, H.F. Nicholson, and J.P. Hughes. 1990. The Iowa state-wide rural well-water survey, water-quality data: Initial analysis. Tech. Info. Ser. 19. Iowa Dep. of Natural Resour., Des Moines.

Laue, H. J.A. Field, and A.M. Cook. 1996. Bacterial desulfonation of the ethanesulfonate metabolite of the chloroacetanilide herbicide metazachlor. Environ. Sci. Technol. 30:1129-1132.

Lerch, R.N., E.M. Thurman, and E.L. Kruger. 1996. Mixed-mode sorption of hydroxylated atrazine degradation products to soil: A mechanism for bound residue. Environ. Sci. Technol. 31:1539-1546.

Martin, J.D. 1999. Quality of pesticide data for environmental water samples collected for the National Water-Quality Assessment Program, 1992-96 and examples of use of quality-control information in water-quality assessments. Available online at http://ca.water. usgs.gov/pnsp/rep/qcsummary/ (verified 12 Sept. 2002). U.S. Geol. Survey, Reston, VA.

Mills, M.S., and E.M. Thurman. 1994. Preferential dealkylation reactions of s-triazine herbicides in the unsaturated zone. Environ. Sci. Technol. 28:600-605.

Papiernik, T.D., S.K. Widmer, and R.F. Spalding. 1996. Effect of various materials in multilevel samplers on monitoring commonly occurring agrichemicals in ground water. Ground Water Monit. Remed. 16:80-84.

Potter, T.L., and T.L. Carpenter. 1995. Occurrence of alachlor environmental degradation products in groundwater. Environ. Sci. Technol. 29:1557-1563.

Roux, P.H., K. Balu, and R. Bennett. 1991. A large-scale retrospective ground water monitoring study for metolachlor. Ground Water Monit. Rev. 11:104-114.

Sorenson, B.A., D.L. Wyse, W.C. Koskinen, D.D. Buhler, W.E. Luechen, and M.D. Jorgenson. 1993. Formation and movement of ${ }^{14} \mathrm{C}$-atrazine degradation products in a sandy loam soil under field conditions. Weed Sci. 41:239-245.

Spalding, R.F., M.E. Burbach, and M.E. Exner. 1989. Pesticides in Nebraska's ground water. Ground Water Monitor. Rev. 9:126-133.

Spalding, R.F., D.G. Watts, D.D. Snow, D.A. Cassada, M.E. Exner, and J.S. Schepers. 2003. Herbicide loading to shallow ground water beneath Nebraska's Management Systems Evaluation Area. J. Environ. Qual. 32:84-91 (this issue).

Spalding, R.F., J.R. Gormly, and K.G. Nash. 1978. Carbon contents and sources in ground waters of the Central Platte Region in Nebraska. J. Environ. Qual. 7:428-434.

Spalding, R.F., G.A. Junk, and J.J. Richard. 1980. Pesticides in ground water beneath irrigated farmland in Nebraska, August 1978. Pestic. Monit. J. 14:70-73.

Spalding, R.F., D.G. Watts, J.S. Schepers, M.E. Burbach, M.E. Exner, R.J. Poreda, and G.E. Martin. 2001. Controlling nitrate leaching in irrigated agriculture. J. Environ. Qual. 30:1184-1194.

Troiano, J., D. Weaver, J. Marade, F. Spurlock, M. Pepple, C. Nordmark, and D. Bartkowiak. 2001. Summary of well water sampling in California to detect pesticide residues resulting from nonpointsource applications. J. Environ. Qual. 30:448-459.

USEPA. 1989. Definition and procedure for the determination of the method detection limit. Revision 1.1. 40 CFR Ch. I Part 136, Appendix B. (7-1-89 ed.). USEPA, Washington, DC.

USEPA. 1990. National survey of pesticides in drinking water wells USEPA 570/9-90-015. USEPA Office of Water, Washington, DC

USEPA. 2000. Drinking water standards and health advisories. USEPA 822-B-00-001. USEPA Office of Water, Washington, DC.

Vargo, J.D. 1998. Determination of sulfonic acid degradates of chloroacetanilide and chloroacetamide herbicides in groundwater by LC/ MS/MS. Anal. Chem. 70:2699-2703. 